\title{
ANALYSIS OF CHANGE OF REGIME OF BNDES. IMPACTS OF PUBLIC SECTOR OVER THE PRIVATE INVESTMENTS.
}

Pedro Ivo Camacho Alves Salvador

Professor do MEGE/ UCAM e Professor do CECS/UFABC

E-mail: p.i.camacho@gmail.com

\begin{abstract}
As soon as BNDES (State Development Bank) change its interest rate calculation methodology, an econometric analysis with panel data is be made, through an endogeneity relationship between the variables investment (private), BNDES loans and market issuance of shares), with the purpose to estimate the impact of the change in interest methodology as early as 2016. The impact on the endogenous variables was estimated and a forecast was made of borrowing costs as well as of private investment. The results corroborate the hypothesis that the BNDES does not encourage new investments, serving only as an alternative financing, which would not justify National Treasury subsidies for new loans. This opens way's for fiscal adjustment but guaranteeing important social programs such as Bolsa Família.

Keywords: BNDES, investment, Panel VAR, impact, TLP.

\section{ANÁLISE DA MUDANÇA DO REGIME DO BNDES. IMPACTOS DO SETOR PÚBLICO SOBRE O INVESTIMENTO PRIVADO.}

\section{RESUMO}

Com a mudança da metodologia do cálculo da taxa de juros do BNDES, far-se-á uma análise econométrica com dados em painel, através de uma relação de endogeneidade entre as variáveis investimento (privado), empréstimos do BNDES e financiamento via mercado (como emissão de ações), de forma a evidenciar qual seria o impacto da mudança da metodologia dos juros já em 2016. Estimou-se o impacto nas variáveis endógenas e fez-se uma previsão dos custos com os empréstimos bem como do investimento privado. Os resultados corroboram a hipótese de que o BNDES não incentiva novos investimentos, servindo apenas como alternativa de financiamento, o que não justificaria subsídios do Tesouro Nacional para novos empréstimos. O que abre espaço para um ajuste fiscal garantindo programas sociais importantes como o Bolsa Família.

Palavras-chave: BNDES, investimento, VAR em painel, impacto, TLP.

\section{INTRODUCTION}

During the second half of the first decade of the twenty-first century, Brazil promoted a turnaround in its economic policy. Acting more incisively and directly in the economy, promoting active policies to stimulate the economy, using financial resources through tax relief, direct and indirect subsidies, as well as credit policies through BNDES and Banco do Brasil ${ }^{1}$. Other fiscal

\footnotetext{
${ }^{1}$ The large public bank of Brazil
}

instruments were used, including fiscal easing's in the Fiscal Responsibility Law itself, to guarantee increased resources for the economic sectors chosen by the federal government, an example followed by the state and municipal governments at a time of global economic contraction.

The consequences of the changes in the management of the economy marked the recent period, coupled with a deterioration in the terms of trade that fell significantly in the period, promoting a decline between 2014 and 2016 of $21 \%$, which led to a reduction in the Brazilian GDP. In terms of macroeconomic policies, the 
moment would be for expansionary countercyclical policies. However, the contrary was promoted, due to the commitment of the public accounts.

Analyzing the period from 2014 to 2016, the interest rates starts from $10 \%$ to $16 \%$ with the SELIC following this trajectory, and with the strong retraction of GDP of $7.2 \%$ in the aggregate of 2015 and 2016, government spending reached a level that began to compromise the public deficit, which advanced from $51 \%$ to $70 \%$ of GDP. In short, the Brazilian economy has entered the so-called perfect storm, with the indicators of employment, investment, inequality and violence receding drastically.

This article evaluates how the monetary policy promoted by the BNDES when targeting subsidized credit could have generated a consubstantial economy, allowing the control of the public accounts, without impacting on social programs. In this pursuit, the bank's loan data for the 47 sectors of the economy were collected, as disclosed by BNDES itself. Each sector is also considered by publicly traded companies, which have shares traded on the stock market, mainly due to their size and representativeness in the Brazilian market. The data of the listed companies will then be used the published data of their respective balance sheets and their income statements.

The criteria for loans granted will not be evaluated, but their consequences in terms of private investment and corporate and corporate policies that are affected by the presence and role of BNDES. The purpose of BNDES's operations is to make investments that would be compromised if they depend only on the market. Its role would be to correct market failures, mainly due to informational asymmetry, which can generate a reduction of available credit below the optimal level. Such asymmetry prevents the market from being able to correctly evaluate the return of the projects. Thus, the risk increases, and the market starts to demand expected rates of return above the average of investments, which would have a positive IRR, if rates of return were collected at international levels.

This paper was divided in introduction, after a discussion about the economic literature of the development banks, the TJLP and the TLP will be analyzed, identifying points of ruptures between the two rates, verifying which will be (post TLP) the new dynamics of the variables, we present the econometric methodology proposed by (SALVADOR, 2017), presenting and discussing the results and promoting a conclusion and next future agenda of the research.

\section{THE DEVELOPMENT BANKS AND THE ECONOMIC LITERATURE}

The recent moves of BNDES are correlated with the mainly role of NDB's as describe by Doctor (2015) such as: financial sector development; business climate enhancement and knowledge services. But, in his analysis the article only approaches the outputs of the Bank, instead measure the tradeoff of input's and output's, to promote an efficiency analysis. The author argues that BNDES remains the mainly long-term source of investments and report some bias between the size of the firms that lies on BNDES's portfolio. With big companies playing a key role on investments of bank, BNDES are stimulating a controversial role, give more incentives to the big ones, instead of the MSME's (micro, small and medium enterprise).

The pattern of development as nations become richer are based on growth of financial intermediaries, growth of banks over credit and role of allocative investment, non-banks institution (such as insurance, investment banks, finance companies, etc.) and finally stock markets become larger, as measured by market capitalization over the GDP. (LEVINE, 1997) In Brazil, at the period of 2002 until 2018, the volume of credit of BNDES and BMF/BOVESPA are tracking different paths. The BMF index that evolve of less then 10\% over 2009 until 2018, on the other hand, the BNDES landings evolve by $97 \%$ over the period.

An analysis of current role of investment policies promoted by BNDES over the aftermath 2008/2009 was made by Ferraz e Coutinho (2017). Was showed that occurs some evolution over the numbers of small and micro firms at BNDES portfolios. But, the percentage of volume of credit isn't growth at the same pace. The authors support the hypothesis that BNDES promoted a pro-cyclical role, but, appointed to another dimension of the mainly roll of NBD, especially at the new age of economic era, which include methodologies for identifying tangible and financial instruments, related to risk capital and risk sharing and an ex-ante impact method coupled with ex-pos monitoring and evaluation processes. There are no mechanisms of 
punishment for companies with bad competitive, social and fiscal conducts, or that do not fit the

Figure 1. BNDES VS BOVESPA

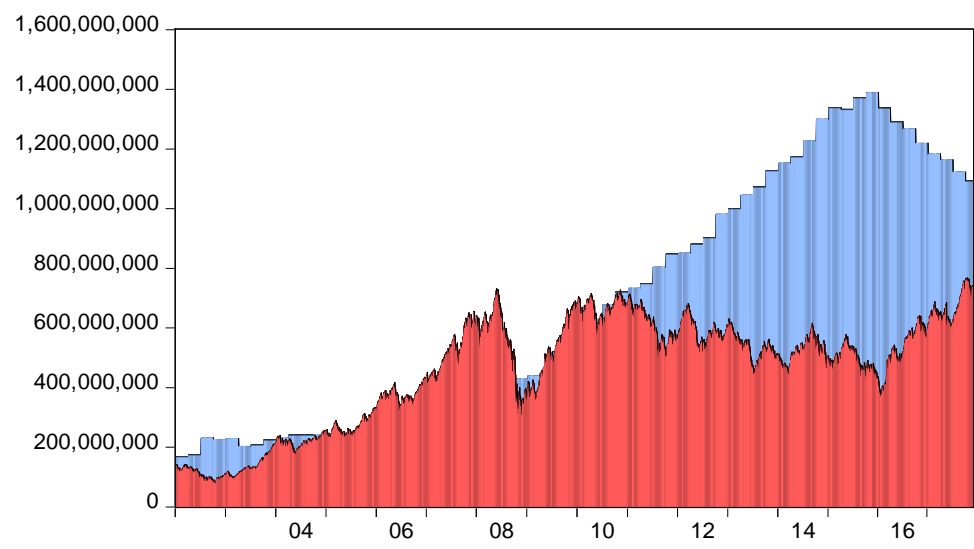

$\square$ BNDES $\square$ ibov

SOURCE: BNDES AND BMF/BOVESPA, VOLUME OF INVESTMENT (BRL), ANO 2017

There is a theory that the long-run and short-run interest rate of countries are converged. Shrestha e Tan (2005) analysis this and found that countries of $\mathrm{G} 7$ has an interest rates that are strongly related over the long-run. But, the countries of non-G7 has a divergence tracking path. These results suggest that monetary policies of the development countries diverge of developing. Special at Brazil, the monetary policy is much more difficult to distinguish, because an increase of base interest rate could be not effect, when put it account the BNDES policy, and his role of stimulate private investment. His principal instrument is TJLP (longrun interest rate) that are 4 p.p. less on average of the SELIC (base interest rate), so, the anti-cycle role of BNDES could diverge of current monetary policy. And this what was occurs in Brazil specially at 2014 period.

At the aftermath 2008 crisis, the Brazilian economy emerge at the biggest and positive response of the negative effect of the subprime crisis. The Brazilian policies of cut of taxes (vertical designed) incentive of private consumption and reduce of interest rates made the GDP grow by $7.2 \%$ at 2010 . But, the long-run GDP tax growth, that are expected of $5 \%$ never more are achieve. The counter crisis package driven the economy in to fiscal abysm, and rises desired profile. 
Figure 2. Rate of BNDES lendings growth

DBNDES

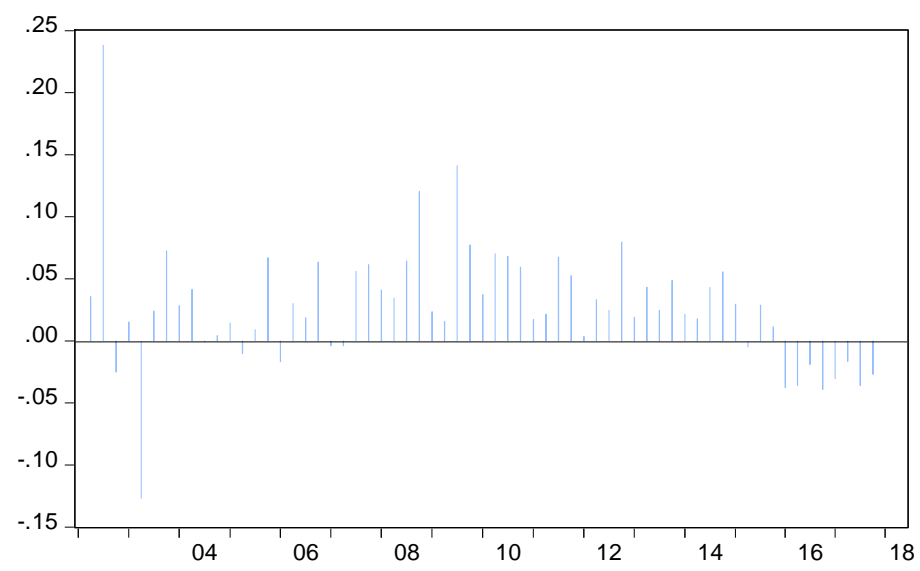

SOURCE: BNDES, ano 2017.

\section{TJP VS TJLP}

The TJLP that was in vigor since 1999 was calculate over inflation target (center of the target for the next year and the other year) plus a risk premium 2. His formula are given by:

$$
T J L P_{t}=\frac{\left[\pi_{T}^{*}(T-t)+\pi_{T+12}^{*}(T-t)\right]}{12}+R
$$

Where: $\pi_{T}^{*}$ is the target inflation for the current year, $\pi_{T+12}^{*}$ is the target inflation for the next year, and $\mathrm{R}$ is the risk premium (that formula isn't announced).

When a comparison is made between the TJLP, SELIC and IPCA (inflation) a wide gap is viewed. Although this gap, the TJLP is used to price contracts tied to all BNDES operations, which have the same cost of funding for the institution, but which have a higher cost for the national treasury, which is SELIC plus a spread. Therefore, all BNDES credit operations have some subsidy involved. The calculation of this cost for the period contemplated in the survey is approximately 450 billion ( $R \$$ ).

When the data are summarized, the average monthly cost of BNDES loans fees are higher than R\$ 1 million. But, sum the total cost of this loans, over the period, the finance volume is about 7 billion of BRL. The real economy of change this subsidies credit policy at 2010 is that 5.29 billion of BRL.

The TLP are be calculate as:

\footnotetext{
${ }^{2}$ This risk premium has incorporate the international interest rate and Brazil risk. But, at any time, his formula was announced. This is the big key for arbitrary or heuristic computation for BNDES loans spread.
}

$$
\begin{aligned}
T L P_{i, t}=(1+ & \left.\pi_{t-2}\right)^{\frac{n d u_{p}}{n d m_{p}}} \times\left(1+\pi_{t-1}\right)^{\frac{n d u_{s}}{n d m_{s}}} \\
& \times\left(1+j_{i}\right)^{\frac{n d u_{p}+n d u_{s}}{252}}-1
\end{aligned}
$$


Table 1. Statistic of Costs

\begin{tabular}{lc}
\hline VARIABLES & $\begin{array}{c}(1) \\
\text { mean } \\
(\mathrm{sd})\end{array}$ \\
\hline cost & $1,176,891.11$ \\
& $(3,540,203.77)$ \\
bndes & $23,020,926.66$ \\
& $(76271378.28)$ \\
market & $46,019,838.69$ \\
& $(22685490.36)$ \\
investment & $54,9195,335.46$ \\
& $(345791208.09)$ \\
dollar & 2.32 \\
& $(0.57)$ \\
inflation & 0.54 \\
& $(0.39)$ \\
Observations & 7,895 \\
Crossid & 47 \\
\hline
\end{tabular}

Figure 3. Cost Of Bndes Loans

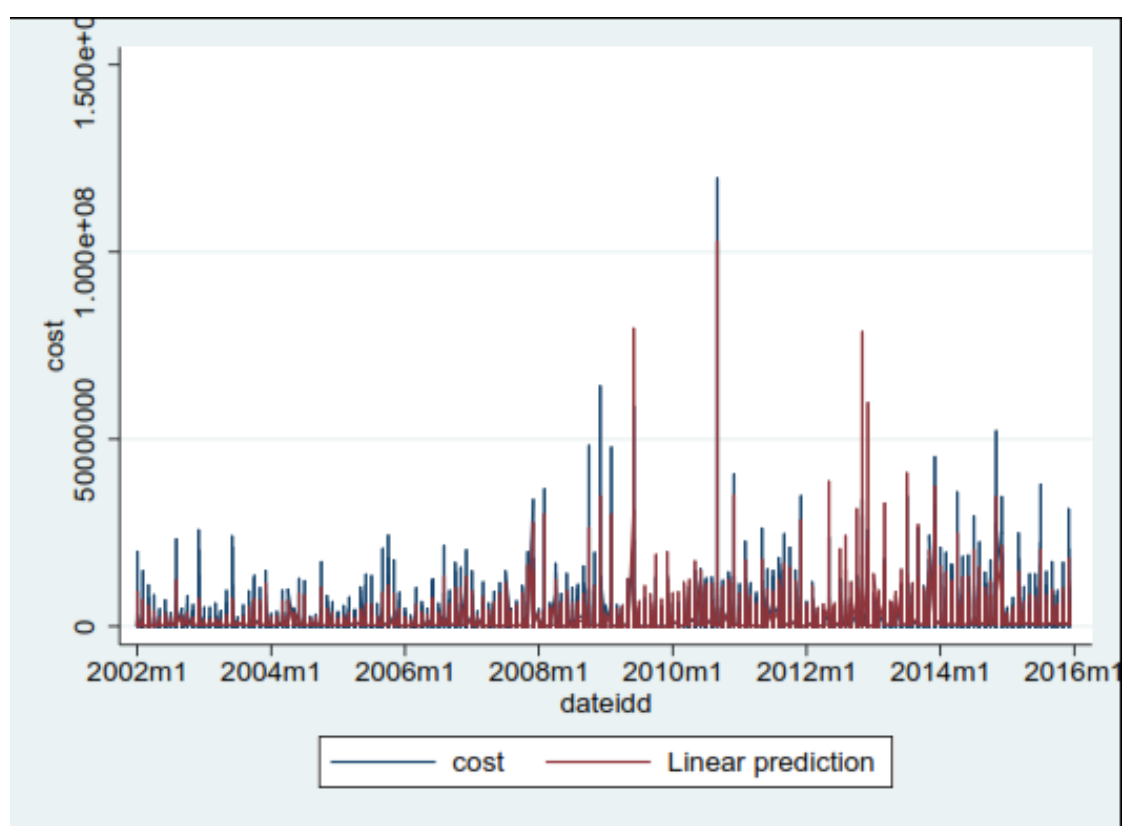

SOURCE: BNDES, BRAZIL CENTRAL BANK, ANO 2017

When the data are summarized, the average monthly cost of BNDES loans fees are higher than R\$ 1 million. But, sum the total cost of this loans, over the period, the finance volume is about 7 billion of BRL. The real economy of change this subsidies credit policy at 2010 is that 5.29 billion of BRL.

The TLP are be calculate as:

$$
\begin{aligned}
T L P_{i, t}=(1+ & \left.\pi_{t-2}\right)^{\frac{n d u_{p}}{n d m_{p}}} \times\left(1+\pi_{t-1}\right)^{\frac{n d u_{s}}{n d m_{s}}} \\
& \times\left(1+j_{i}\right)^{\frac{n d u_{p}+n d u_{s}}{252}}-1
\end{aligned}
$$

Where, $T L P_{i, t}$ is the new rate of the month $\mathrm{t}$ to the $\mathrm{i}$ parcel, $\pi_{t-1}$ is the real inflation (measured by IPCA) to the first month before $t$, $\pi_{t-2}$ is the real inflation to the second month before $\mathrm{t}, j_{i}=\frac{a_{k} J_{t}}{100}$ where $J_{t}$ is the simple arithmetical average of interest rate of NTN-B (treasure bond) for the 5 years of term structure. Every $n d u_{x}$ is the number of commercial days of $\mathrm{x}$ month and $n d m_{x}$ is the number of current days of $x$ month.

The comparison of the two formulas emerge the consequence of TLP to bring balance to investment loans of Long-Run. The TLP is now price the real inflation, instead the inflation target, this second was never achieved perfectly at never period of current inflation target policy. And use one not arbitrary risk premium which is the NTN-B yield to maturity instead of heuristic term $R$, that formula isn't publish, and for all series that BNDES announced the term is equal to 0 .

\section{IDENTIFICATION STRATEGY}

For estimation of the effect of BNDES intervention in the credit and financing market of large companies, divided by sectors, and accompanying them for the years 2002 to 2016, the data were grouped in the panel format, and for that purpose, an econometric methodology that allows to study the relations between the variables Market, BNDES and Assets. As the endogenous relationships between these three variables, and a group of exogenous variables, the first is the exemptions promoted by the federal government towards the sectors contemplated by the sample. The other exogenous variables are: GDP, interest, foreign exchange. These variables are correlated according to economic theory and company performance.

It is sought to identify the response of the Companies' Asset, which according to the Balance Sheet: Assets = Liability + Equity, represents the capital invested in the company, and such capital can have two origins according to this equation, equity constituted by Shareholders' Equity, and that in the case of companies can be capitalized via the Stock Exchange, through the sale and trading of a fraction of its capital stock, or capital of third parties constituted by the Liabilities that, in turn, may be capitalized 
through debt, contracted with financial institutions, such as the BNDES or also with debt issuance, which may even be a market instrument such as debentures and promissory notes.

The proposed econometric methodology is a Panel Autoregressive Vector (PVAR) model, which allows analyzing the structure of shocks between endogenous variables and their dependent variables, as well as analyzing the decomposition of variance between the variables in their structural form, and its summary form allows to make predictions for the variables under analysis. The purpose of the analysis is the responses of the Asset that represents the private investment in relation to shocks in the financing promoted by BNDES. In addition, the answers between the three variables are analyzed.

Panel analysis allows deal with unobserved factors that are constant over time, such as a linear time trend. In addition, since the sample includes 47 sectors analyzed in monthly data from January 2002 to December 2015, there are a total of 7896 observations.

Equations can be divided into linear format like:

$$
\begin{aligned}
\text { Ativo }_{i t}=\beta_{0}+ & \sum_{j=1}^{2} \theta_{j} \text { Ativo }_{i t-j} \\
& +\sum_{j=0}^{2} \mu_{j} \text { Mercado }_{i t-j} \\
& +\sum_{j=0}^{2} \sigma_{j} \text { Bndes }_{i t-j}+\sum_{j=1}^{\rho} \lambda_{j} C_{j t} \\
& +\varepsilon_{i t}^{2} \\
\text { Mercado }_{i t}= & \beta_{0}+\sum_{j=1}^{2} \theta_{j} \text { Mercado }_{i t-j} \\
& +\sum_{j=0}^{2} \mu_{j} \text { Bndes }_{i t-j} \\
& +\sum_{j=0}^{2} \sigma_{j} \text { Ativo }_{i t-j}+\sum_{j=1}^{\rho} \lambda_{j} C_{j t} \\
& +u_{i t}
\end{aligned}
$$

$$
\begin{aligned}
\text { Bndes }_{i t}=\beta_{0} & +\sum_{j=1}^{2} \theta_{j} \text { Bndes }_{i t-j} \\
& +\sum_{j=0}^{2} \mu_{j} \text { Mercado }_{i t-j} \\
& +\sum_{j=0}^{2} \sigma_{j} \text { Ativo }_{i t-j}+\sum_{j=1}^{\rho} \lambda_{j} C_{j t} \\
& +\alpha_{i t}
\end{aligned}
$$

In terms of the matrix equation, you have the following configuration:

$$
\begin{aligned}
& \underbrace{\left[\begin{array}{c}
\text { Ativo } \\
\text { Mercado } \\
\text { Bndes }
\end{array}\right]_{i, t}}_{X_{t}}=\underbrace{\left[\begin{array}{lll}
a_{11} & a_{12} & a_{13} \\
a_{21} & a_{22} & a_{23} \\
a_{31} & a_{32} & a_{33}
\end{array}\right]_{i}}_{A_{3 \times 3}} \\
& * \sum_{j=1}^{2}\left[\begin{array}{c}
\text { Ativo } \\
\text { Mercado } \\
\text { Bndes }
\end{array}\right]_{i, t-j} \\
& +\sum_{j=1}^{p}\left[\theta_{i} C\right]+\left[\begin{array}{l}
\varepsilon \\
u \\
\alpha
\end{array}\right]_{i t}
\end{aligned}
$$

From matrix $A$ and vector estimation $\vec{\theta}$ The effects of the variables $C$ (control) where the interest will be included. It is calculated the impact of interest on investments and loans via the market and via BNDES. With this, one can estimate the impact of a reduction in the interest

rate on each of the variables: $\nabla X_{t}=\left[\begin{array}{c}\frac{\partial A \text { Ativo }}{\partial J \text { Juros }} \\ \frac{\text { Mercado }}{\partial J \text { Juros }} \\ \frac{\partial B N D E S}{\partial J \text { Juros }}\end{array}\right]$,

where if the signal is positive it is indicative that the effect will be increasing. A declining interest rate is expected on market financing and growing on BNDES financing, and that after the term of TLP, this dynamic is reversal.

\section{DATA BASE}

The data collected from BNDES funding has been extracted from the bank's own website, which has A ratio of borrowed volumes to the 47 sectors of the economy Month by month. The company's assets were collected in the consulting data Economática as well as the capitalized resources via the market. As the sectors of the economy divided by BNDES do not Following the sectors of CNAE, it was a time-consuming task to concatenate the data, to ensure consistency in the organization of the database.

The observations of the SELIC rate, Exchange (RS/US\$), gross domestic product (GDP) and the broad Consumer Price index 
(IPCA). Such data were collected in the IPEADATA, whereas observations on interest rates in the United States and the European Union were collected in the Federal Reserve Economic Date and in the Eurostat, respectively.

The data from the market financing, and Fiscal easing of taxation where found, respecatively at Economática, the site From the IRS $\mathrm{Br}$. However, each of the bases presents a distinct sectoral division, so that the basis of the Economática that uses the classification North American Industry Classification System (NAICS) and the BNDES an proper classification of its own with 47 sectors, which was respected, because it was synthetic, and did not have the names of the companies that were destined for the resources.

To solve the classification problem, a filter was development to convert the sectors. In addition, the IRS uses a CNAE classification other than that of the BNDES, since the basis of this is more extensive than that. Therefore, the BNDES base turns out to be more detailed than that of the IRS. The solution found was also divide the amount observed for the macro-sectors of IRS database into micro-sectors of BNDES base.

\section{RESULTS}

The tests of stationarity of the series showed that endogenous variables are stationary. Therefore, was included 4 lag terms for each endogenous variable at level. This is an important issue due to the stationarity of the endogeneity variables series, and its relationship with the others variables (exogeneous and endogenous).

Table 2. Stationarity tests for endogenous variables.

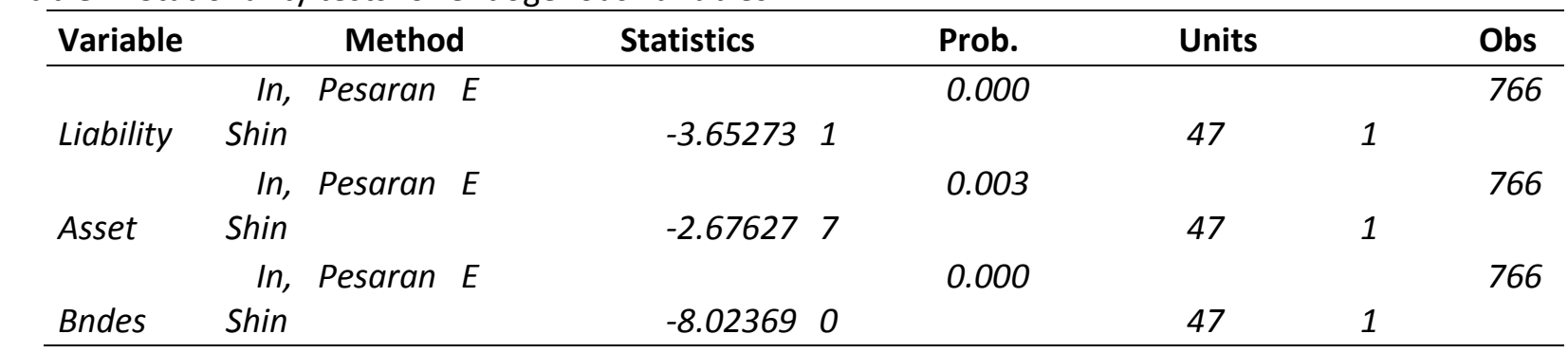

SOURCE: OWN ELABORATION, ANO 2019

The goal is to compute the impulse response function (IRF) of assets and market financing (market) to BNDES loans (bndes) and make a comparison with the same results change only the interest rate of the loans (included as exogeneous variable).

The principal estimation model is reported at Table 3, and the fit of $R^{2}$ for assets (private investment) and for market (liability or debit finance source) was $92.87 \%$ and $99.57 \%$ respectively for the first estimation (using TJLP the actual interest rate of BNDES for the data's) and $92.82 \%$ e $99.58 \%$ for the second estimation (using TLP). The negligible difference between the sum of squares estimated for the market can be explain due the lower impact of TLP or TJLP at each variable - include the BNDES loans, what is controversy.

The controversy of the estimate impact of TLP/TJLP at BNDES loans emerge because the source for news lending's and an metric of success and indicator of effectiveness of BNDES have to be correlate with TLP/TJLP, otherwise the
State Bank don't use his mainly price variable to compute his profit, which is very contradictory, and such estimation will be analyzed more carefully in further papers.

The dollar price and inflation have a negative effect over investment, market and BNDES as predictable by economic theory. Dollar price, at an floating exchange regime is an good indication for expectancy of the market investors over the real economy, if the dollar price arise, this is an indicator that the confidence level for the real economy is lower, and the contrary analogue induction is true. (NOGUEIRA; SHIKIDA; ARAUJO, 2011).

The fiscal easing promoted by federal government at 2010 until 2015 (at the first year of second government of Dilma Roussef) has a negative impact over the new investment, but has an positive effect over the market (credit) and BNDES, what is an indicator that this policy was in fact an countercyclical policy, what means that will act more effect at lower economic 
activity moments, and contrary analogue induction is true.

The model's results suggest that, on average, there is no changing over the relations between the endogenous variables, but, all tree variables are less sensible at changings in interest rate when the TJLP was replaced. This model performed a good fit for liability and asset, but a poor fit (in comparison) to BNDES loans, this is an indication that's variable's dynamic presents a poor correlation with the controls variables and endogenous variables. Which means that, either liability or asset are a good proxy for BNDES loans, and the control variables present's a bad proxy for variation over this loan. This behavior is plausible due to arbitrary loans politic of BNDES, that are correlated with a policy decision instead a data driven decision. Otherwise the market and controls variables, which had a good fit, by our model.

The model made forecasting's for the three series, where the green line is the assets, the red is the liability and the blue one is the BNDES loans. There is a bit of variation between forecasting's on begin of series. When all 47 sectors are merged, the variation was neglectable. The liability and BNDES loans are only new debt strategy's, like new equities, debentures, loans and securitization. The variation of the begin of the series is explain due to was used only 2010 over 2015 actual data's. The rest of the forecasting sample was estimated by the static forecast (that use the first and last actual data for predictable - back and forecasting - all the data's).

The economy estimate for the new interest rate is combine with no significantly reduce in assets. The impulse response function of assets is still with the same behavior over TJLP vis à vis TLP. There is a logic argument for this, when decision makers can access the BNDES loans, they are doing by a solution of frontier, that is, they consume all available resources, therefore, BNDES loans still competitive with lower or the same interest rate of Brazilian treasure bond. Note that, eve with TLP there is no spread at BNDES loans, that's conclude that all BNDES cost of agency are negligible (but, there isn't).

The IRF for two estimation models is the non-accumulate response. The Figure 5 shows that the new interest rate policy isn't change the impact of BNDES loans over new investments. The negligible impact of the first over the second variable (BNDES to Ativo) is an indication that BNDES isn't effect for stimulate the investment and the future output. Beyond that, the nonnegligible cost of BNDES operation works like taxation over the entire economy, and at period of growth debit rate, this cost has an explosive trajectory.

If the analyzes is correct, the liability of new debts for new investment respond as expected over positive shocks on new investments (Mercado over Ativo). This is an indication that market's rule variables are more predictable and more theory adherent than variables that has an arbitrary build rule, like BNDES loans policy and its interest rate rule. The only variable that has a theory adherent movement was the fiscal easing, that are positive correlate with new BNDES loans and news liability from the market. But the BNDES estimation has a poor fit, and a non-economic theory behavior. This is an indication that an improvement of this model is necessary, but an arbitrary policy could not allow such estimation. 
Figure 4. SERIES FORECASTING (PVAR): TLP VS TJLP
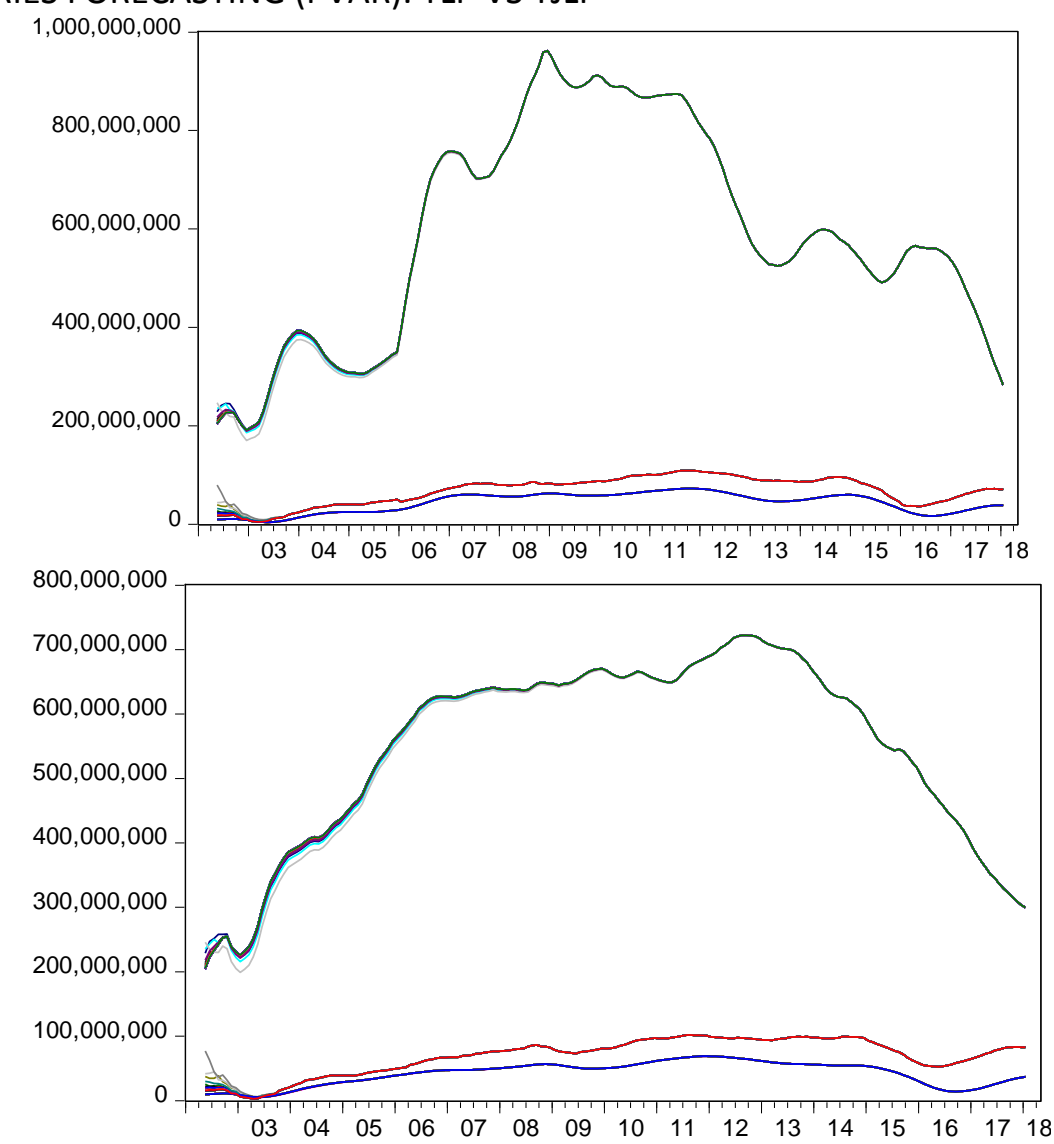

SOURCE: OWN COMPILATION, ANO 2019

\section{CONCLUSION}

In this paper a forecasting essay was made, in order to predict what is the real impact of public sector interest rate policy over the private investment. The recent regime changing at BNDES loans interest rate incorporate an rational expectative regime for inflation and term structure of interest rate. The strategy of identification to achieve a robust estimation for this impact, was build up a panel with 47 sectors over Jan/2002 to Dec/2015. The PVAR estimation indicates that there is no strong relationship between BNDES loans and news investments. And, our estimative for BNDES loans policy has been a poor fit, in comparative with the others two endogenous variables. This isn't a concern of this paper, but it is an evidence that BNDES policy for land resources isn't correlate with the variables include in the build model.

For estimate the impact of TLP (new policy rule) over the private investment, was made a inclusion of another exogenous variable, to incorporate the change on BNDES interest rate loans. This change was not affecting to reverse the relation of IRF of private investment and BNDES loans. This indicate that a positive shock at BNDES loans isn't effect for modify the private investment. One possible assumption for such behavior is that BNDES loans is only one alternative for finance an already decision made investment. So, the decision for news investments isn't made by BNDES credit line.

The average economy of subsidized credit estimate is about 1.2 million (BRL) for each month and each sector (47 sectors and 14 years times 12 months), what will perform a nonnegligible economy of resources. Beyond that, our mainly contribution is achieved the IRF for new private investments over BNDES loan's. And we estimate that a positive shock at second variable will promote a negligible impact at the first variable. Therefore, the BNDES politics isn't efficiency to stimulate news investments.

The agenda for next papers will incorporate the qualitative fiscal easing promoted by Federal Government at 2010 until 2015 and evaluated its role in terms of stimulate the aggregate supply. The second spinoff will be estimate the demand curve, and elasticities interest ratio of demand for private investment, using as instrumental variables the Taylor rules (KOZICKI, 1999) for interest long run term and inflation expected ratio. Therefore, the endogeneity problem between interest rate and 
demand for credit will be fixed, due by Taylor rule and inflation target policy adopted in Brazil since 1999. Beyond this, the final improve in our methodology is obtain the microdata's from BNDES loans over the company level, without any aggregate. Doing this we'll incorporate any disposal information of BNDES loans policy, and we can perform an evaluation of this policy in terms of efficiency and efficacy. 
Figure 5. Impulse response function estimation TJLP vis a vis tlp.

Response of BNDES to Cholesky One S.D. Innovation

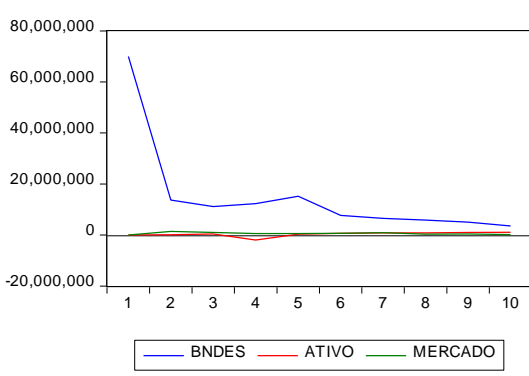

Response of ATIVO to Cholesky

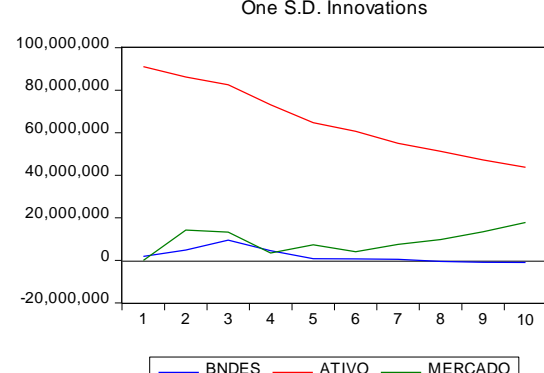

Response of MERCADO to Cholesky One S.D. Innovations

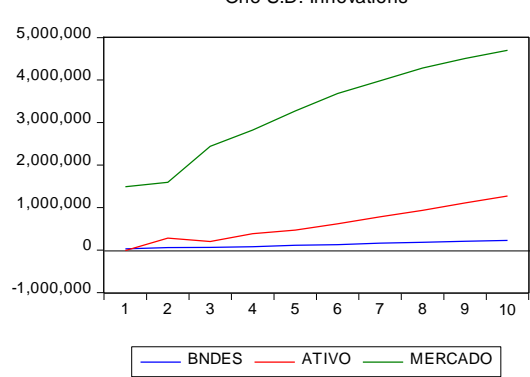

OWN

- ${ }^{\text {BNDES _ ATIVO _ MERCADO }}$

SOURCE:
Response of BNDES to Cholesky One S.D. Innor

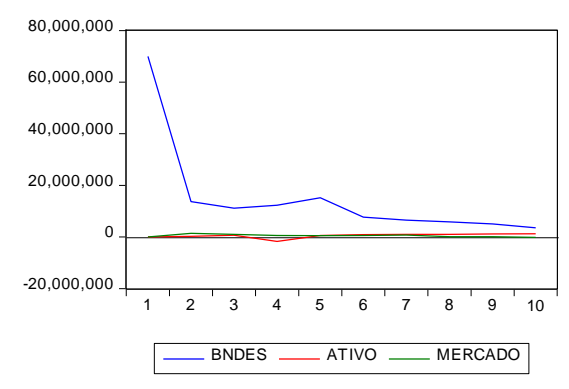

Response of ATIVO to Cholesky One S.D. Innovations

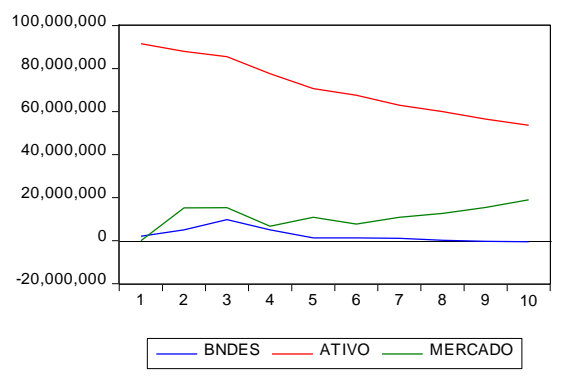

Response of MERCADO to Cholesky One S.D. Innovations

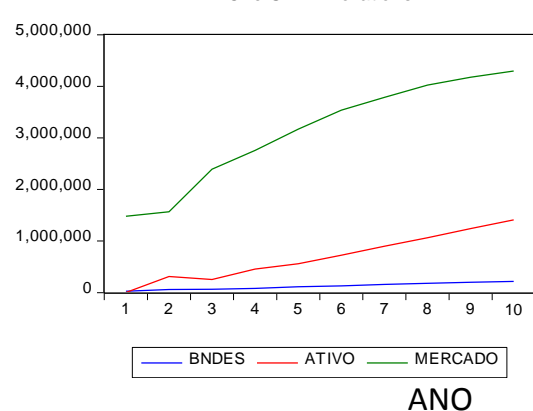


Table 3. Estimation of the PVAR

\section{PVAR model Results}

\begin{tabular}{|c|c|c|c|c|c|c|}
\hline \multirow[b]{2}{*}{ Variables } & \multicolumn{3}{|c|}{ TLP } & \multicolumn{3}{|c|}{ TJLP } \\
\hline & Asset & Market & BNDES & Asset & Market & BNDES \\
\hline Active1 & $\begin{array}{l}0.974 \\
0.011\end{array}$ & $\begin{array}{l}0.003 \\
0.000\end{array}$ & $\begin{array}{l}0.000 \\
0.008\end{array}$ & $\begin{array}{l}0.976 \\
0.011\end{array}$ & $\begin{array}{l}0.003 \\
0.000\end{array}$ & $\begin{array}{c}-0.001 \\
0.008\end{array}$ \\
\hline Active-2 & $\begin{array}{c}-0.021 \\
0.016\end{array}$ & $\begin{array}{c}-0.004 \\
0.000\end{array}$ & $\begin{array}{l}0.000 \\
0.012\end{array}$ & $\begin{array}{c}-0.022 \\
0.016\end{array}$ & $\begin{array}{c}-0.004 \\
0.000\end{array}$ & $\begin{array}{l}0.001 \\
0.012\end{array}$ \\
\hline Active-3 & $\begin{array}{c}-0.023 \\
0.016\end{array}$ & $\begin{array}{l}0.001 \\
0.000\end{array}$ & $\begin{array}{l}-0.024 \\
0.012\end{array}$ & $\begin{array}{c}-0.026 \\
0.016\end{array}$ & $\begin{array}{l}0.001 \\
0.000\end{array}$ & $\begin{array}{c}-0.023 \\
0.012\end{array}$ \\
\hline Active-4 & $\begin{array}{l}0.020 \\
0.012\end{array}$ & $\begin{array}{l}0.000 \\
0.000\end{array}$ & $\begin{array}{l}0.027 \\
0.009\end{array}$ & $\begin{array}{l}0.014 \\
0.012\end{array}$ & $\begin{array}{l}0.001 \\
0.000\end{array}$ & $\begin{array}{l}0.029 \\
0.009\end{array}$ \\
\hline Market-1 & $\begin{array}{l}9.851 \\
0.707\end{array}$ & $\begin{array}{l}1.023 \\
0.011\end{array}$ & $\begin{array}{l}0.912 \\
0.536\end{array}$ & $\begin{array}{l}9.770 \\
0.713\end{array}$ & $\begin{array}{l}1.011 \\
0.011\end{array}$ & $\begin{array}{l}0.846 \\
0.539\end{array}$ \\
\hline Market-2 & $\begin{array}{c}-9.672 \\
0.998\end{array}$ & $\begin{array}{l}0.465 \\
0.016\end{array}$ & $\begin{array}{c}-0.721 \\
0.757\end{array}$ & $\begin{array}{c}-9.472 \\
1.003\end{array}$ & $\begin{array}{l}0.476 \\
0.016\end{array}$ & $\begin{array}{c}-0.685 \\
0.759\end{array}$ \\
\hline Market-3 & $\begin{array}{c}-10.730 \\
0.973\end{array}$ & $\begin{array}{c}-0.318 \\
0.015\end{array}$ & $\begin{array}{c}-0.800 \\
0.738\end{array}$ & $\begin{array}{c}-10.599 \\
0.976\end{array}$ & $\begin{array}{c}-0.316 \\
0.015\end{array}$ & $\begin{array}{c}-0.813 \\
0.738\end{array}$ \\
\hline Market-4 & $\begin{array}{c}11.201 \\
0.689\end{array}$ & $\begin{array}{c}-0.209 \\
0.011\end{array}$ & $\begin{array}{l}0.642 \\
0.523\end{array}$ & $\begin{array}{c}10.720 \\
0.698\end{array}$ & $\begin{array}{c}-0.227 \\
0.011\end{array}$ & $\begin{array}{l}0.619 \\
0.527\end{array}$ \\
\hline BNDES(-1) & $\begin{array}{l}0.038 \\
0.015\end{array}$ & $\begin{array}{l}0.000 \\
0.000\end{array}$ & $\begin{array}{l}0.193 \\
0.011\end{array}$ & $\begin{array}{l}0.035 \\
0.015\end{array}$ & $\begin{array}{l}0.000 \\
0.000\end{array}$ & $\begin{array}{l}0.193 \\
0.011\end{array}$ \\
\hline BNDES(-2) & $\begin{array}{l}0.058 \\
0.015\end{array}$ & $\begin{array}{l}0.000 \\
0.000\end{array}$ & $\begin{array}{l}0.118 \\
0.011\end{array}$ & $\begin{array}{l}0.055 \\
0.015\end{array}$ & $\begin{array}{l}0.000 \\
0.000\end{array}$ & $\begin{array}{l}0.119 \\
0.011\end{array}$ \\
\hline BNDES(-3) & $\begin{array}{c}-0.077 \\
0.015\end{array}$ & $\begin{array}{l}0.000 \\
0.000\end{array}$ & $\begin{array}{l}0.120 \\
0.011\end{array}$ & $\begin{array}{l}-0.080 \\
0.015\end{array}$ & $\begin{array}{l}0.000 \\
0.000\end{array}$ & $\begin{array}{l}0.120 \\
0.011\end{array}$ \\
\hline BNDES(-4) & $\begin{array}{l}-0.050 \\
0.015\end{array}$ & $\begin{array}{l}0.001 \\
0.000\end{array}$ & $\begin{array}{l}0.138 \\
0.011\end{array}$ & $\begin{array}{c}-0.051 \\
0.015\end{array}$ & $\begin{array}{l}0.001 \\
0.000\end{array}$ & $\begin{array}{l}0.138 \\
0.011\end{array}$ \\
\hline $\mathrm{C}$ & $\begin{array}{c}-2.33 \mathrm{e}^{\wedge} 07 \\
1.47 e 07\end{array}$ & $\begin{array}{l}3.97 \mathrm{e} 06 \\
2.32 e 05\end{array}$ & $\begin{array}{c}1.06 \mathrm{e}+07 \\
1.11 e 07\end{array}$ & $\begin{array}{c}1.70 \mathrm{e} 07 \\
1.94 e 07\end{array}$ & $\begin{array}{l}6.18 \mathrm{e} 06 \\
3.03 e 05\end{array}$ & $\begin{array}{l}1.74 \text { e } 07 \\
1.47 e 07\end{array}$ \\
\hline Dollars & $\begin{array}{c}-7.02 \mathrm{e} 06 \\
3.64 e 06\end{array}$ & $\begin{array}{c}-8.86 \mathrm{e} 05 \\
5.74 \text { e } 04\end{array}$ & $\begin{array}{l}3.40 \text { e } 06 \\
2.76 e 06\end{array}$ & $\begin{array}{c}-5.91 \mathrm{e} 06 \\
3.71 e 06\end{array}$ & $\begin{array}{c}-1.00 \mathrm{E}+06 \\
5.79 e 04\end{array}$ & $\begin{array}{l}2.37 \text { e } 06 \\
2.80 e 06\end{array}$ \\
\hline INFLATION & $\begin{array}{c}-7.73 \text { e } 06 \\
3.14 \text { e } 06\end{array}$ & $\begin{array}{c}-2.46 \mathrm{e} 05 \\
4.96 e 04\end{array}$ & $\begin{array}{c}-2.23 \text { e } 06 \\
2.38 e 06\end{array}$ & $\begin{array}{c}-3.65 \mathrm{e} 06 \\
3.10 e 06\end{array}$ & $\begin{array}{c}-2.58 \mathrm{e} 05 \\
4.84 \text { e } 04\end{array}$ & $\begin{array}{c}-3.15 \mathrm{e}+06 \\
2.34 e 06\end{array}$ \\
\hline TJLP vs. TLP & $\begin{array}{l}3.23 \text { e } 06 \\
4.39 e 05\end{array}$ & $\begin{array}{c}-2.74 \text { e } 04 \\
6.93 e 03\end{array}$ & $\begin{array}{l}-8.55 \text { e } 05 \\
3.33 e 05\end{array}$ & $\begin{array}{c}2.06 \mathrm{e} 06 \\
1.23 e 06\end{array}$ & $\begin{array}{c}-2.19 \mathrm{e} 05 \\
1.92 e 04\end{array}$ & $\begin{array}{c}-1.92 \mathrm{e} 06 \\
9.28 e 05\end{array}$ \\
\hline EASING & $\begin{array}{c}-7.19 \mathrm{e} 04 \\
2.90 e 04\end{array}$ & $\begin{array}{c}6.86 \mathrm{e} 02 \\
4.58 e 02\end{array}$ & $\begin{array}{l}1.03 \mathrm{e}+05 \\
2.20 E+04\end{array}$ & $\begin{array}{c}-1.00 \mathrm{e} 05 \\
2.92 e 04\end{array}$ & $\begin{array}{c}6.26 \mathrm{e} 01 \\
4.55 e 02\end{array}$ & $\begin{array}{l}1.05 \text { e } 05 \\
2.20 e 04\end{array}$ \\
\hline R-squared & $92.87 \%$ & $99.57 \%$ & $17.76 \%$ & $92.82 \%$ & $99.58 \%$ & $17.73 \%$ \\
\hline
\end{tabular}

SOURCE: OWN ELABORATION, ANO 2019 


\section{REFERENCES}

AFONSO, J. R. Politica Fiscal No Brasil No

Contexto da Crise (Fiscal Policy: Brazilian Fiscal

Policy in Crisis Context). Social Science

Research Network, 2010.

https://doi.org/10.2139/ssrn.3000369

DOCTOR, M. Assessing the changing roles of the Brazilian Development Bank. Bulletin of Latin American Research, v. 34, n. 2, p. 197-213, 2015. https://doi.org/10.1111/blar.12210

FERRAZ, J. C., ; COUTINHO, L. (2017). Investment policies, development finance and economic transformation: lessons from BNDES. Structural Change and Economic Dynamics: Elsevier, 2017.

KOZICKI, S. How useful are Taylor rules for monetary policy. Econometric Reviews,v. 84, n. 2, p. 5-33, 1999.

LEVINE, R. Financial Development and Economic Growth: Views and Agenda. Journal of Economic Literature, p. 688-726, 1997.

NOGUEIRA, R. P.; SHIKIDA, C. D., ; ARAUJO, A. F. Structural changes in exchange rate regimes in Brazil. Economics Bulletin, v. 31, n. 2, p. 17481756, 2011.

SALVADOR, P. I. The crowding-out effect via BDB in the 21st century's Brazilian. Espacios, p. 8-29, 2017.

SHILLER, R. J., CAMPBELL, J. Y. , SCHOENZHOLTZ, K. L., WEISS, L. . Forward Rates and Future Policy: Interpreting the Term Structure of Interest Rates. Brookings Papers on Eocnomic Activity, p. 173223, 1983.

https://doi.org/10.2307/2534355

SHRESTHA, K., ; TAN, K. H. Real Interest Rate Parity: Long-Run and Short-Run Analysis Using Wavelets. Review of Quantitative Finance and Accounting, v.25, n. 2, p. 139-157, 2005. https://doi.org/10.1007/s11156-005-4246-8
Recebido para publicação em 29/03/2019

Revisado em 18/04/2019

Aceito em 30/04/2019 